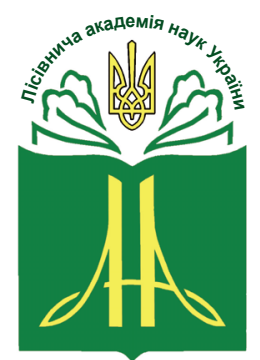

Forestry Academy of Sciences of Ukraine
Наукові праці Лісівничої академії наук України Proceedings of the Forestry Academy of Sciences of Ukraine http://fasu.nltu.edu.ua https://doi.org/10.15421/412113

Article received 2020.12.25

Article accepted 2021.06.10
ISSN 1991-606X print

ISSN 2616-5015 online

(a) $\triangle$ Correspondence author

Stepan Myklush msi_s@ukr.net
General Chuprynka str., 103, Lviv, 79057, Ukraine

УДК $630 * 5$

\title{
Стиглі букові деревостани у різних категоріях лісів рівнинної частини України
}

\author{
С.І. Миклуш ${ }^{1}$, Ю.С. Миклуш ${ }^{2}$, С. А. Гаврилюк ${ }^{3}$, Ю. М. Дебринюк ${ }^{4}$, В. М. Савчин ${ }^{5}$
}

За матеріалами обліку лісового фонду визначено площі стиглих букових насаджень у виділених лісовпорядкуванням 21 категорії лісів та лісових ділянок. Встановлено, щзо понад 57\% стиглих деревостанів за площею зосереджено в експлуатаційних лісах та 15,7\% - у лісогосподарській частині зелених зон. Стиглі букові насадження ростуть у букових, дубових, ялицевих та соснових типах лісу, але переважають в умовах свіжої грабової бучини займаючи понад 10 тис. га та вологої грабової бучини - 8,5 тис га. Насадження формуються за частки бука лісового у складі від 2 до 10 одинищь. В окремих регіонах поряд з буком у складі беруть участь дуб звичайний, ялиия біла, сосна звичайна, а супутникали найчастіме є граб звичайний, клени явір та гостролистий, береза повисла, осика. В експлуатаційних лісах зосереджено понад $52 \%$ чистих за складом деревостанів як за площею так $i$ за кількістю ділянок. Найпотиренішими є насадження з відносною повнотою 0,5, що охоплюють площу майже 7,4 тис. га (1762 ділянки) та з повнотою 0,7, площа яких 7,3 тис. га, i які ростуть на 1150 ділянках. Найвищою продуктивністю стиглі букові лісостани характеризуються в лісогосподарській частині лісів зелених зон, де їхні запаси в окремих насадженнях сягають 590-661 $\mathrm{m}^{3} \cdot 2 \mathrm{a}^{-1}$.

Виконання буковими насадженнями різнопланових функиій потребує застосування лісогосподарських заходів, які найповніше відповідають меті господарювання, постійному збереженню лісового середовища, посиленню виконання насадженнями визначених функиій, вчасному та якісному природному відновленню лісових ділянок. У більшості категорій лісів і лісових ділянок, зокрема, у рекреаційно-оздоровчих лісах і лісах, щяо виконують екологічні та охоронні функиії, вимагається здійснення заходів для поступового переформування одновікових букових лісостанів у різновікові складної структури.

Ключові слова: матеріали лісовпорядкування; лісівничо-таксаиійні показники; функції; природне поновлення; рубки головного користування.

Миклуш Степан Іванович - академік Лісівничої академії наук України, доктор сільськогосподарських наук, директор ННІ лісового і садово-паркового господарства, професор кафедри лісової таксації та лісовпорядкування. Національний лісотехнічний університет України, вул. Генерала Чупринки, 103, м. Львів, 79057, Україна. Тел.: 032-237-10-45,+38-067-791-36-77. E-mail: msi_s@ukr.net ORCID: 0000-0002-9762-1190

2 Миклуш Юрій Степанович - кандидат сільськогосподарських наук, доцент кафедри лісової таксації та лісовпорядкування. Національний лісотехнічний університет України, вул. Генерала Чупринки, 103, м. Львів, 79057, Україна. Тел.: 032-239-27-46, +38-067-750-3826. E-mail: y.myklush@nltu.edu.ua ORCID: 0000-0002-1940-1045

Гаврилюк Сергій Анатолійович - кандидат сільськогосподарських наук, доцент кафедри лісової таксації та лісовпорядкування. Національний лісотехнічний університет України, вул. Генерала Чупринки, 103, м. Львів, 79057, Україна. Тел.: 032-239-27-46, +38-068-76091-99. E-mail: serhiy_havrylyuk@nltu.edu.ua ORCID: 0000-0003-0361-0624

4 Дебринюк Юрій Михайлович - академік Лісівничої академії наук України, академік-секретар ЛАН України, доктор сільськогосподарських наук, професор кафедри лісових культур і лісової селекції. Національний лісотехнічний університет України, вул. Генерала Чупринки, 103, м. Львів, 79057, Україна. Тел.: 032-235-30-12,+38-067-195-78-36. E-mail: debrynuk_ju@ukr.net ORCID: http://orcid. org/0000-0002-0994-349X

5 Савчин Володимир Миколайович - головний технолог. ВО «Укрдержліспроект», вул. Чайковського, 17, м. Львів, 79005. Тел.: +38-097011-40-47. E-mail: svm_25@ukr.net 
Вступ. Рівнинні букові ліси в Україні є одними iз найвагоміших природних утворень внаслідок значних площ лісостанів, представлених у лісовому фонді більшості областей (Криницький, Попадинець, Бондаренко, Крамарець, 2004; Миклуш, 2011), специфічного флористичного складу (Сорока, 2008), високої продуктивності (С. І. Миклуш, 2011, Pretzsch et al., 2015) та важливості виконуваних ними функцій (С. I. Миклуш, 2011; S. I. Myklush, Y. S. Myklush, \& Savchyn, 2017). Зважаючи на багатофункціональне ведення лісового господарства у букових лісах, їх збереження, посилення виконання ними екологічних функцій для запобігання природним катаклізмам необхідна відмова від суцільнолісосічних способів рубок головного користування та застосування рубок, що забезпечують постійне збереження лісового середовища із використанням технологій, які сприятимуть природному поновленню корінних деревостанів. За результатами тривалих досліджень особливостей росту та відновлення букових насаджень дослідниками рекомендовано в них проводити поступові і вибіркові рубання (Rubner, 1960; Молотков, 1972; Мальцев, 1980; Тышкевич, 1984). Формування природних букових лісів є особливо важливим у гірській і горбистій місцевостях, де середовище-стабілізуючі та захисні функції букових лісостанів мають визначальне значення, оскільки деревостани зі значною часткою бука $є$ стійкими до несприятливих природних явищ (вітровалів, сніголамів) та рідше піддаються ураженням хворобами та пошкодженням шкідниками. Поряд із виконанням захисних і середовищетвірних функцій, букові насадження $є$ джерелом цінної деревини, що дає змогу забезпечити економіку держави діловою деревиною та вирішувати енергетичні проблеми.

У зв'язку з цим, аналіз стану і структури стиглих букових лісостанів у різних категоріях лісів потребують поглибленого вивчення 3 метою напрацювання підходів щодо їх різнопланового та ефективного використання.

Об'єкти та методика досліджень. Об 'єкт дослідження - лісовий фонд стиглих букових лісостанів в умовах рівнинної частини України. Дослідженнями охоплено природні і штучні, корінні та похідні букові насадження, які ростуть у Вінницькій, Закарпатській, Івано-Франківській, Львівській, Рівненській, Тернопільській, Хмельницькій, Черкаській та Чернівецьких областях. Предмет дослідження - особливості формування запасів букових деревостанів під впливом лісогосподарських заходів та раціональне їх використання.

Meта роботи полягає в аналізі лісівничотаксаційної характеристики стиглих букових деревостанів рівнинної частини України та пропозиції лісівничих підходів щодо ведення господарства в них.

Дослідження лісівничо-таксаційних показників букових деревостанів проводили за загальноприйнятими методиками (Гром 2005; Гірс, Новак, Кашпор, 2014; Нормативно-справочные материа- лы..., 1987). Типи лісорослинних умов і типи лісу визначали за принципами лісівничо-екологічної типології на основі аналізу складу і продуктивності деревостанів, складу підліску і надгрунтового покриву, типу грунту (Горшенин, Бутейко, 1962; Воробьев, 1967; Герушинський, 1996; Остапенко, Ткач, 2002). Опрацювання основних таксаційних показників здійснювали 3 дотриманням вимог біометрії (Горошко, Миклуш, Хомюк, 2004).

Результати та обговорення. За актуалізованими даними лісовпорядкування станом на 01.01.2017 p., площа стиглих букових лісостанів становить 28860,2 га, які ростуть на 5632 ділянках. Стиглі насадження природного походження охоплюють понад 99\% площ.

Стиглі букові деревостани представлені у 21-ій категорії лісів та лісових ділянок, які лісовпорядкування виділяло як категорії захисності. Категорії лісів і лісові ділянки виділено відповідно до вимог нормативних матеріалів щодо порядку поділу лісів на категорії та виділення особливо захисних лісових ділянок (Закон України..., 1992; Постанова КМУ ..., 2007). За невеликих площ окремих категорій лісових ділянок у національних природних парках та регіональних ландшафтних парках, господарська і заповідна зони та зона регульованої рекреації національних природних парків, а також господарська зона та зони стаціонарної і регульованої рекреації регіональних ландшафтних парків об'єднані між собою (табл. 1). Найбільша площа стиглих букових деревостанів (понад 57\%) зосереджена в експлуатаційних лісах та $15,7 \%$ - в лісогосподарській частині лісів зелених зон. На значних площах стиглі букові лісостани збережені у заказниках (7,6\%), регіональних ландшафтних парках $(9,2 \%)$, національних природних парках $(4,2 \%)$ та лісопарковій $(2 \%)$ частині лісів зелених зон.

Необхідно зауважити, що до категорії стиглих віднесені деревостани з широким розмахом їхнього віку - від 81 до 170 років. Аспект зумовлений тим, що оборот рубки головного користування у відповідних категоріях лісів та лісових ділянок встановлюють 3 урахуванням віку стиглості (кількісної, технічної чи природної) та функцій, які насадження виконують. За межею природної стиглості структура насаджень змінюється внаслідок відмирання окремих дерев, і виконання функцій деревостаном суттєво погіршується.

Стиглі букові насадження ростуть у букових, дубових, ялицевих та соснових типах лісу. У букових типах лісу деревостани з переважанням бука формуються на площі понад 25 тис. га, у дубових їх площа перевищує 1,5 тис. га, в ялицевих - 1,2 тис. га. На площі понад 30 га ростуть сосново-букові деревостани. Тобто, переважна частина стиглих букових насаджень зосереджена у букових типах лісу - майже 90\%, з яких 91,6\% зосереджена безпосередньо у бучинах. Стиглі насадження переважають в умовах свіжої грабової бучини - на площі понад 10 тис. га та вологої грабової бучини - на площі більше 8,5 тис. га, які ростуть на більше ніж 3400 ділянках (табл. 2). 
Площі та кількість ділянок букових насаджень за категоріями лісових ділянок

\begin{tabular}{lccc}
\hline \multicolumn{1}{c}{ Категорії лісів і лісових ділянок } & Площа, га & Кількість ділянок, шт. & Частка площі, \% \\
\hline Байрачні (ліси в балках) та інші захисні ліси & 101,7 & 34 & 0,4 \\
Експлуатаційні ліси & 16646,0 & 3133 & 57,7 \\
Заказники & 2198,5 & 501 & 7,6 \\
Заповідні лісові урочища & 383,3 & 36 & 1,3 \\
Ліси 1 та 2 зон округів санітарної охорони & 12,0 & 5 & 0,0 \\
Ліси 3 зони округів санітарної охорони & 22,5 & 8 & 0,1 \\
Ліси наукового призначення & 257,8 & 18 & 0,9 \\
Ліси протиерозійні & 28,5 & 1 & 0,1 \\
Ліси в межах населених пунктів & 163,2 & 42 & 0,6 \\
Ліси вздовж берегів річок, водойм & 311,5 & 77 & 1,1 \\
Ліси вздовж смуг відведення автомобільних доріг & 63,1 & 24 & 0,2 \\
Ліси вздовж смуг відведення залізних доріг & 53,8 & 9 & 0,2 \\
Лісогосподарська частина лісів зеленої зони & 3952,7 & 857 & 13,7 \\
Лісопаркова частина лісів зеленої зони & 569,6 & 113 & 2,0 \\
Національні природні парки (господарська і & 1205,2 & 254 & 4,2 \\
заповідна зони та зона регульованої рекреації) & 239,3 & 30 & 0,8 \\
Пам'ятки природи & 2651,5 & 490 & 9,2 \\
Регіональні ландшафтні парки (господарська зона & & 5632 & 100 \\
та зони стаціонарної і регульованої рекреаціі) & 28860,2 & & \\
\hline Разом & & 24 & \\
\hline
\end{tabular}

Таблиия 2

Найбільші площі букових насаджень у букових, дубових, ялицевих і соснових типах лісу

\begin{tabular}{lccc}
\hline $\begin{array}{c}\text { Індекс типу } \\
\text { лісу }\end{array}$ & $\begin{array}{c}\text { Площа, } \\
\text { га }\end{array}$ & $\begin{array}{c}\text { Кількість } \\
\text { ділянок, шт. }\end{array}$ & $\begin{array}{c}\text { Частка } \\
\text { площі, } \%\end{array}$ \\
\hline \multicolumn{5}{c}{ Букові типи лісу } \\
$\mathrm{D}_{2}$-ГБк & 10007,5 & 1727 & 17,3 \\
$\mathrm{D}_{3}$-ГБк & 8523,2 & 1687 & 14,8 \\
$\mathrm{C}_{3}$-Г-яцБк & 485,6 & 83 & 0,8 \\
$\mathrm{C}_{2}$-гБк & 325,1 & 75 & 0,6 \\
\hline \multicolumn{5}{c}{ Дубові типи лісу } \\
$\mathrm{D}_{2}$-бкД & 454,6 & 105 & 0,8 \\
$\mathrm{C}_{3}$-бкД & 107,1 & 34 & 0,2 \\
\hline \multicolumn{5}{c}{ Ялицеві типи лісу } \\
$\mathrm{D}_{3}$-Г-бкЯц & 415,4 & 74 & 0,7 \\
$\mathrm{C}_{3}$-дЯц & 124,1 & 37 & 0,2 \\
\hline \multicolumn{5}{c}{ Соснові типи лісу } \\
$\mathrm{C}_{2}$-Г-дС & 11,9 & 4 & 0 \\
\hline
\end{tabular}

Загалом у субучинах стиглі деревостани займають площу майже 2,2 тис. га, що становить $3,8 \%$ від загальної площі, а найпоширенішими типами лісу є волога грабово-ялицева субучина 3 площею майже 500 га та свіжа грабова субучина, де частка площі становить $0,6 \%$. У дубових типах лісу букові деревостани переважають в умовах свіжої букової діброви, де букові деревостани ростуть на 105 ділянках площею понад 450 га. У соснових типах лісу букові деревостани сформувались лише на чотирьох ділянках.

Найбільша площа букових лісостанів зосереджена на території Західного Лісостепу - у різних лісорослинних умовах Українського Розточчя, Опілля та Західного Поділля (Дебринюк, 2003).

Залежно від кількості деревних видів, що беруть участь у складі насаджень, до букової господарської секції віднесені деревостани з часткою бука лісового у складі від 2 до 10 одиниць (рис. 1). У складі стиглих деревостанів в окремих регіонах, поряд 3 буком лісовим, беруть участь дуб звичайний, ялиця біла (Прикарпаття), сосна звичайна (Розточчя), а супутниками найчастіше виступають граб звичайний, клени явір та гостролистий, береза повисла, осика. На більш ніж 5 тис. ділянках, тобто майже на 91,5\% від загальної кількості, формуються насадження за частки бука 5 та більше одиниць. На пло- 
щі 8,98 тис. га (понад 1600 ділянок) формуються деревостани 3 часткою 10 одиниць бука у складі насаджень, що становить $31,1 \%$ від загальної площі. Окрім цього, на площі 9,3 тис. га (1687 ділянок) формуються деревостани за частки бука 8 та 9 одиниць.

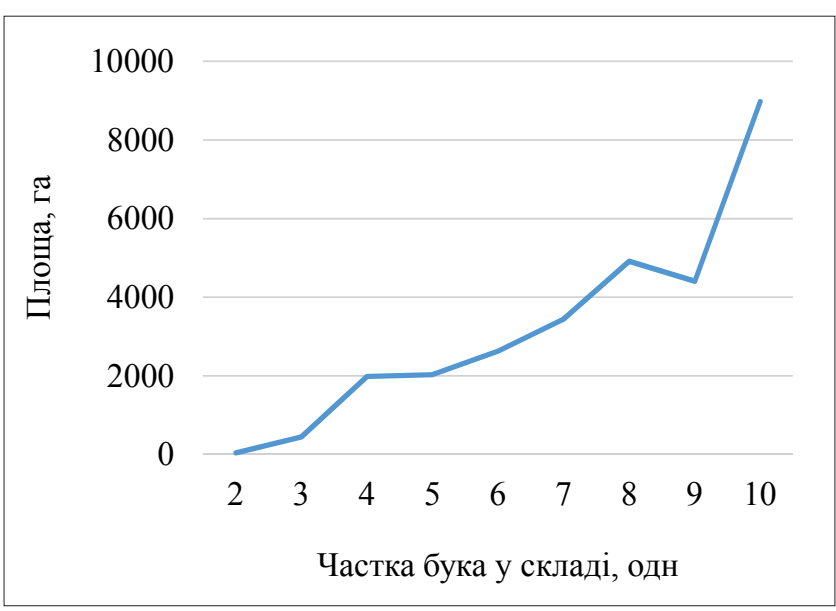

Рис. 1. Площі стиглих насаджень за різної частки бука

Необхідно відзначити, що лісовпорядкуванням не виділено стиглих букових насаджень за відносної повноти 1,0 (рис. 2). На площі 58 га формуються насадження за відносної повноти 0,9 , а найпоширенішими $€$ насадження 3 відносною повнотою 0,5 , що охоплюють площу майже 7,4 тис. га (1762 ділянки) та 3 повнотою 0,7 , площа яких становить 7,3 тис. га, і які ростуть на 1150 ділянках. Відносною повнотою 0,2-0,4 характеризуються насадження на площі 1058 га, що не перевищує 14\% від загальної площі, а частка площ насаджень 3 відносною повнотою 0,8 складає $12,5 \%$.

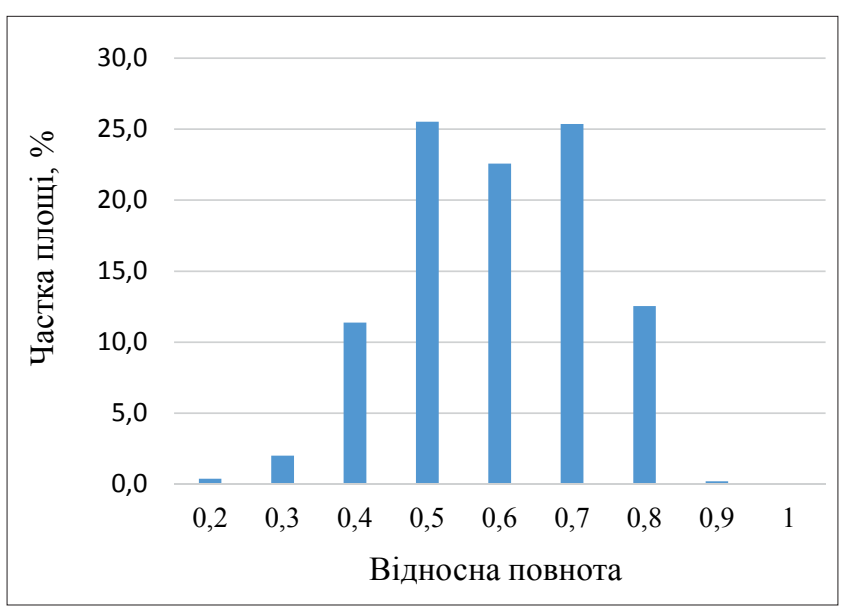

Рис. 2. Розподіл площ букових деревостанів за відносною повнотою

Рівнинні букові ліси виконують 54 первинні функції, серед яких важливе значення відведене соціальному та охоронному типу функцій (Миклуш, 2011), тому структура насаджень має бути оптимальною для їх ефективного виконання впродовж тривалого періоду (табл. 3). Зважаючи на виділені категорії лісів і лісових ділянок, реалізовані на практиці підходи щодо організації ведення лі- сового господарства, доцільно для кожної 3 них застосовувати форми господарства, які б дали змогу поліпшувати структуру лісостанів, не допускати погіршення стану насаджень та розладнання їхньої просторової структури до віку природної стиглості, забезпечувати поступове омолодження насаджень. Разом 3 тим, беручи до уваги відмінності у відносних повнотах насаджень, що формуються в аналізованих категоріях лісів і лісових ділянок, особливо за відносної повноти 0,2-0,6, структура насаджень не $є$ оптимальною. У переважній частині категорій лісів та лісових ділянок відносні повноти у стиглих букових деревостанах не перевищують 0,6 і лише в протиерозійних лісах, які представлені однією ділянкою, мають найвище значення $(0,72)$. При цьому необхідно зауважити, що лише в експлуатаційних лісах ведеться інтенсивне господарювання, а в переважній більшості лісів та лісових ділянок, зокрема в тих, що виконують соціальні та екологічні функції - заповідниках, заказниках, національних парках, ліси в межах населених пунктів - господарювання обмежене.

Зважаючи на необхідність постійного збереження лісового середовища для виконання буковими лісами соціальних та екологічних функцій, посилення їх рекреаційно-оздоровчих можливостей необхідно в цих категоріях лісів планувати заходи поступового переформування насаджень у різновікові зі складною просторовою структурою.

Дослідженнями встановлено, що високопродуктивні букові деревостани ефективно виконують як соціальні, так і екологічні та охоронні функціï (С. I. Миклуш, 2011; S. I. Myklush, Y. S. Myklush, \& Savchyn, 2017), тому у структурі букових деревостанів має бути достатньою частка бука у складі за рівномірного розміщення дерев на площі, що забезпечить стійкість і продуктивність насаджень. Кількість ділянок 3 часткою бука у складі від 2 до 5 одиниць не значна. В середньому частка бука у складі деревостанів аналізованих категорій лісів і лісових ділянок знаходиться в межах 6,0-9,9 одиниць. Досліджувані насадження характеризуються часткою бука у від 3 до 10 одиниць практично в усіх категоріях за винятком заказників, де зосереджено 11 з 14 ділянок насаджень 3 часткою 2 одиниці бука у складі і які, очевидно, створені для охорони та збереження біорізноманіття тварин чи рослин в ареалі формування букових лісів. Найбільша частка чистих за складом букових деревостанів зосереджена в експлуатаційних лісах - понад $52 \%$, як за площею, так і за кількістю ділянок.

Поряд 3 виконуваними буковими насадженнями різноплановими функціями необхідно відзначити, що завдяки значній зольності опаду бук збагачує грунт (Бутейко, 1963; Pretzsch et al., 2015). Букові насадження затримують значну кількість вологи та регулюють поверхневий стік (Кульчицький-Жигайло, Приболотна, Ошуркевич, 2007; Козій, КульчицькийЖигайло, 2013), зменшують амплітуду температур, очищають від пилу та підвищують вологість повітря, чим створюють комфортні умови для відпо- 
чинку (Кучерявий, 2001). Враховуючи вище сказане, формування насаджень за значної частки бука у складі має важливе значення.

Район розміщення, лісорослинні умови та лісогосподарські заходи, що проводять у стиглих букових насадженнях, позначаються на їхніх запасах, які, залежно від відносної повноти, знаходяться в межах 93-661 м³.га-1. Найвищими середніми запасами характеризуються ліси наукового призначення $-448 \mathrm{~m}^{3} \cdot \mathrm{ra}^{-1}$ та заповідні ліси $-400 \mathrm{~m}^{3} \cdot \mathrm{ra}^{-1}$, а найнижчі запаси у байрачних лісах (букові ліси в балках).

Таблиия 3

\section{Основні лісівничо-таксаційні характеристики букових насаджень у різних категоріях лісів} та лісових ділянок

\begin{tabular}{|c|c|c|c|c|}
\hline \multirow[b]{2}{*}{ Тип функції } & \multirow[b]{2}{*}{ Категорії лісів і лісових ділянок } & \multicolumn{3}{|c|}{ Середнє значення } \\
\hline & & $\begin{array}{c}\text { частки бука, } \\
\text { од. }\end{array}$ & $\begin{array}{c}\text { відносної } \\
\text { повноти }\end{array}$ & $\begin{array}{l}\text { запасу, } \\
\mathrm{m}^{3} \cdot \mathrm{ra}^{-1} \\
\end{array}$ \\
\hline \multirow{10}{*}{ Соціальний } & Байрачні та інші захисні ліси & 7,6 & 0,53 & 270 \\
\hline & Заказники & 6,3 & 0,57 & 322 \\
\hline & Заповідні лісові урочища & 8,6 & 0,54 & 400 \\
\hline & Ліси наукового призначення & 8,8 & 0,69 & 448 \\
\hline & Ліси в межах населених пунктів & 6,3 & 0,58 & 297 \\
\hline & Лісогосподарська частина лісів зеленої зони & 7,7 & 0,58 & 314 \\
\hline & Лісопаркова частина лісів зеленої зони & 8,1 & 0,55 & 316 \\
\hline & Національні природні парки & 8,4 & 0,56 & 305 \\
\hline & Пам’ятки природи & 8,4 & 0,58 & 351 \\
\hline & Регіональні ландшафтні парки & 8,5 & 0,57 & 312 \\
\hline \multirow{2}{*}{ Екологічний } & Ліси 1 та 2 зон округів санітарної охорони & 6,5 & 0,63 & 354 \\
\hline & Ліси 3 зони округів санітарної охорони & 7,8 & 0,59 & 311 \\
\hline \multirow{4}{*}{ Охоронний } & Ліси протиерозійні & 6,0 & 0,72 & 375 \\
\hline & Ліси вздовж берегів річок, водойм & 7,9 & 0,65 & 379 \\
\hline & Ліси вздовж смуг відведення автомобільних доріг & 7,0 & 0,54 & 280 \\
\hline & Ліси вздовж смуг відведення ж/д доріг & 9,9 & 0,53 & 282 \\
\hline Сировинний & Експлуатаційні ліси & 7,8 & 0,56 & 287 \\
\hline
\end{tabular}

Аналіз запасів за окремими ділянками показує, що найвищою продуктивністю характеризуються стиглі букові деревостани в лісогосподарській частині лісів зелених зон, де в окремих насадженнях ДП «Чернівецьке ЛГ» та «Стрийське ЛГ» зафіксовано запаси 590-661 м³.га-1. На окремих ділянках експлуатаційних лісів також формуються високопродуктивні деревостани із запасами 520-590 м ма $^{-1}$, зокрема, у лісових масивах ДП «Берегометське ЛМГ», а також Чернівецького, Хотинського і Стрийського лісгоспів. У букових насадженнях наукового призначення, які виділені у лісовому фонді ДП «Бібрське ЛГ» та «Сторожинецьке ЛГ», найбільші значення запасів перевищують 520, досягаючи $560 \mathrm{~m}^{3} \cdot \mathrm{ra}^{-1}$. Високі запаси насаджень у рекреаційно-оздоровчих лісах і лісах наукового призначення вказують на обмежений антропогенний вплив у них, про що свідчать зазвичай високі відносні повноти. Необхідно відзначити, що найнижчі запаси букових деревостанів (93$\left.120 \mathrm{~m}^{3} \cdot \mathrm{ra}^{-1}\right)$ зафіксовані в експлуатаційних лісах і лі- сах лісогосподарської частини лісів зелених зон за відносної повноти 0,3, тобто перед заключним прийомом поступової рубки.

Наведений аналіз відносних повнот та запасів стиглих букових деревостанів показує, що незалежно від виконання ними визначених функцій практично в усіх категоріях лісів і лісових ділянок виконані перший чи другий прийоми поступової рубки головного користування. Незважаючи на значне різноманіття відомих способів рубок головного користування (Горшенин, Швиденко, 1977; Свириденко, Бабич, Киричок, 2005), правилами рубок головного користування (Правила рубок ..., 2009) у букових насадженнях залежно від їх структури та характеру відновлення, передбачено призначення таких рубок:

- добровільно-вибіркові 3 інтенсивністю рубки до $20 \%$ запасу;

- триприйомні рівномірно-поступові рубки у насадженнях 3 повнотою 0,9 i більше чи двоприйомні рубки у деревостанах 3 повнотою 0,6-0,8; 
- групово-поступові рубки за наявності куртинного життєздатного підросту цінних порід;

- суцільні (у разі, якщо основним способом лісовідновлення може бути тільки створення лісових культур, у деревостанах з повнотою 0,5 і менше проводять вузьколісосічні рубки).

Також у різновікових, складних за будовою, нерівномірних за повнотою та розміщенням дерев лісостанах, що віднесені до лісів природоохоронного, наукового, історико-культурного призначення можуть виконувати і комбіновані рубки, але в рівнинних умовах держави різновікові букові деревостани практично відсутні.

Віднесення площ лісових ділянок 3 переважанням букових насаджень до виділених лісовпорядкуванням категорій лісів і лісових ділянок, виконання ними різнопланових функції потребує застосування лісогосподарських заходів, а в стиглих деревостанах - рубок головного користування, які найповніше відповідають меті господарювання, постійному збереженню лісового середовища, посиленню виконання насадженнями середовищних функцій, вчасному та якісному поновленню лісових ділянок. Враховуючи біоекологічні особливості бука лісового, здатність деревного виду до природного відновлення, лісогосподарські заходи у стиглих букових насадженнях, незалежно від виконуваних ними функцій, повинні бути спрямовані на їхнє природне відновлення та поступове переформування у різновікові лісостани складної структури.

За результатами досліджень у пристигаючих стиглих букових деревостанах в умовах Стільського горбогір'я (Целень, 2006), поряд з високою продуктивністю та репродуктивним потенціалом, під наметом досліджуваних деревостанів нагромаджено значну кількість підросту бука різних вікових і висотних груп, а успішність природного поновлення значною мірою залежить від зімкнутості крон. Таким чином, шляхом застосування рубок головного користування з урахуванням кількості і стану підросту цінних деревних видів під наметом букового деревостану можна забезпечити ефективне природне відновлення букових лісостанів.

Для вивчення характеру відновлення букових насаджень за десяти різних способів рубок головного користування та їхнього впливу на екологічні функції лісових екосистем, у 2003 р. науковцями НЛТУ України за участю спеціалістів Львівського обласного управління лісового господарства в умовах вологої грабової бучини ДП «Бібрське ЛГ» на площі 13 га закладено 11 стаціонарних пробних площ (Бусько, Криницький, Миклуш, Целень, 2006). У лісовому фонді Західно-Подільського горбогір'я і Гологорах вивчали результативність таких способів рубок: суцільна вузьколісосічна; рівномірна поступова двоприйомна; Вагнера; рівномірна поступова триприйомна; улоговинна триприйомна; добровільно-вибіркова; групово-вибіркова триприйомна; суцільна лісосічна; гніздово-вибіркова; добровільно-вибіркова сильної інтенсивності. Попередні результати засвідчили, що суттєвий вплив головних рубань на появу підросту бука лісового проявляється переважно на третій рік, а конкретні висновки щодо формування молодого покоління та його розвитку можуть бути зроблені за підсумками тривалого дослідження.

У зв'язку зі значним різноманіттям функцій рівнинних букових лісів, інтенсивним веденням господарства та впливом лісогосподарських заходів на особливості відновлення та формування насаджень, їхню структуру та продуктивність, одними iз першочергових завдань у букових насадженнях виступають:

- опрацювання заходів у пристигаючих і старших класах середньовікових деревостанів для забезпечення умов природного відновлення корінних продуктивних насаджень;

- уточнення обороту рубки в деревостанах відповідно до їх функціонального призначення з урахуванням віку природної стиглості;

- застосування способів рубок головного користування, які б забезпечували постійне збереження лісового середовища та омолодження насаджень для посилення виконання їхніх середовищнозахисних функцій.

Висновки. У рівнинних умовах України стиглі букові насадження представлені у 21 категорії лісів і лісових ділянок. Найбільша їхня частка за площею (понад 57\%) представлена в експлуатаційних лісах та $15,7 \%$ зосереджено у лісогосподарській частині лісів зелених зон.

Стилі букові насадження ростуть у букових, дубових, ялицевих та соснових типах лісу 3 часткою бука лісового у складі від 2 до 10 одиниць. В експлуатаційних лісах зосереджено понад $52 \%$ чистих за складом деревостанів як за площею, так і за кількістю ділянок. Найпоширенішими $є$ насадження 3 відносною повнотою 0,5 , що охоплюють площу майже 7,4 тис. га (1762 ділянки) та 3 повнотою 0,7 , площа яких становить 7,3 тис. га, і які ростуть на 1150 ділянках. Найвищою продуктивністю характеризуються стиглі букові деревостани у лісогосподарській частині лісів зелених зон, де запаси деревини в окремих насадженнях сягають 590-661 м³. га ${ }^{-1}$.

Виконання буковими насадженнями різнопланових функцій потребує застосування лісогосподарських заходів, які найповніше відповідають меті господарювання, постійному збереженню лісового середовища, посиленню виконання насадженнями визначених функцій, вчасному та якісному природному поновленню лісових ділянок. У рекреаційнооздоровчих лісах і лісах, що виконують екологічні та охоронні функції, необхідно здійснювати заходи 3 поступового їх переформування у різновікові лісостани складної структури.

\section{Список літератури}

Бусько М.М., Криницький Г.Т., Миклуш С.I., Целень Я.П. (2006). Структура і таксаційна характеристики букових насаджень Суходільсь- 
кого стаціонару НЛТУ України. Науковий вісник Національного лісотехнічного університету України, 16.5, 21-24. [Busko, M.M., Krynytskyi, G. T., Myklush, S. I. \& Tselen, Ya. P. (2006). Structure and assessment characteristics of beech stands of Sukhodil permanent plots of UNFU. Scientific Bulletin of the Ukrainian National Forestry University, 16.5, 21-24. Retrieved from https://nv.nltu.edu.ua/Archive/2006/16_5/21_Busko 16_5.pdf] (in Ukrainian)

Бутейко О.І. (1963). Сосново-букові ліси, їх поширення та збереження в західних районах СРСР. У кн. «Матеріали для вивчення природних ресурсів Поділля» (с. 18-28). Тернопіль-Кременець: Поділля [Buteyko, O.I. (1963). Pine-beech forests, their distribution and conservation at the Western regions of USSR. In Materials for the study of natural resources of Podillia (pp. 18-28). Ternopil-Kremenets: Podillia] (in Ukrainian)

Воробьев Д.В. (1967). Методика лесотипологических исследований. Киев: Урожай. 388 с. [Vorobyov, D.V. (1967). Methodology of the forest typology research. Kiev: Harvest] (in Russian)

Герушинський 3.Ю. (1996). Типологія лісів Українських Kарпат. Львів: Піраміда. 208 с. [Gerushinsky, Z.Yu. (1996). Typology of forests of the Ukrainian Carpathians. Lviv: Piramida] ISBN 5-77639366-3 (in Ukrainian)

Гірс О.А., Новак Б.І., Кашпор С.М. (2014) Лісовпорядкування. Київ: Фітосоціоцентр. 434 с. [Girs O.A., Novak B. I., \& Kashpor, S. M. (2014). Forest management. Kyiv: Phytosocial center] (in Ukrainian)

Горошко М.П., Миклуш С.І., Хомюк П.Г. (2004). Біометрія. Львів: Камула. 236 с. [Goroshko, M.P., Myklush, S. I., \& Khomyuk, P. H. (2004). Biometry. Lviv: Kamula] (in Ukrainian)

Горшенин Н. М., Бутейко А. И. (1962). Определение типов условий местопроизрастания. Львов: ЛЛТИ. 230 с. [Gorshenyn, N.M., \& Buteyko, A.I. (1962). Determination of types of site conditions. Lviv: Lviv Forestry Institute] (in Russian)

Горшенин Н.М., Швиденко А.И. (1977). Лесоводство. Львов: Вища школа. 304 с. [Gorshenin, N. М., \& Shvydenko, A. I. (1977). Forestry. Lviv: Higher school] (in Russian)

Гром М. М. (2005). Лісова таксація. Львів: НЛТУ України. 352 с. [Grom, М. М. (2005). Forest assessment. Lviv: Ukrainian National Forestry University] (in Ukrainian)

Дебринюк Ю.М. (2003). Лісокультурне районування Західного Лісостепу України. Львів: Камула. 248 c. [Debryniuk, Iu. (2003). Forest zoning of the Western Forest-steppe of Ukraine: Lviv: Kamula] (in Ukrainian)

Закон Украӥни «Про природо-заповідний фонд України» (1992). Київ. Отримано $3 \mathrm{https} / / /$ zakon. rada.gov.ua/laws/show/2456-12\#Text [Law of Ukraine "On the Nature and Reserve Fund of Ukraine" (1992). Kyiv. Retrieved from https: //zakon.rada.gov.ua/laws/ show/2456-12\#Text] (in Ukrainian)

Козій Н. І., Кульчицький-Жигайло I. Є. (2013). Формування стоку дощових паводків 3 малого карпатського водозбору та його різнозаліснених частин. Лісове господарство, лісова, паперова та деревообробна промисловість, 39.1, 13-19. [Koziy, N.I., \& Kulchytskyy-Zhyhaylo, I.Ye. (2013). Forming of rain floods flow from the small Carpathian catchment and its parts with different percentage of forest cover. Forestry, Forest, Paper and Woodworking Industry, 39.1, 13-19] (in Ukrainian)

Криницький Г.Т., Попадинець I.M., Бондаренко В.Д., Крамарець В.О. (2004). Букові ліси Західного Поділля. Тернопіль: Укрмедкнига. 168 с. [Krynytskyi, H.T., Popadynets, I. M., Bondarenko, V.D., \& Kramarets, V.O. (2004). Beech forests of the Western Podillya. Ternopil: Ukrmedknyga] (in Ukrainian)

Кульчицький-Жигайло I. Є., Приболотна Н.C., Ошуркевич О.Є. (2007). Вплив робіт з експлуатації лісу на формування поверхневого стоку та розвиток ерозійних процесів у Бескидах. Лісівниитво та агролісомеліорація, 111, 111-116. [Kulchytskyy-Zhyhaylo, I. Ye., Pribolotna, N. S., \& Oshurkevych, O.E. (2007). Influence of forest exploitation works on the formation of surface runoff and development of erosion processes in the Beskids. Forestry and Forest Melioration, 111, 111-116] (in Ukrainian)

Кучерявий В.П. (2001). Екологія: Львів: Світ. 480 с. [Cucherjavyy, V.P. (2001). Ecology. Lviv: Swit] (in Ukrainian)

Мальцев М.П. (1980) Бук. Москва: Лесная промышленность. 82 с. [Maltsev, M. P. (1980). Beech. Moscow: Forestry Industry] (in Russian)

Миклуш С.I. (2011). Рівнинні букові ліси України: продуктивність та організація сталого господарства. Львів: ЗУКЦ. 259 с. [Myklush, S.I. (2011). Plain beech forests of Ukraine: productivity and organizing sustainable forestry in them: monography. Lviv: ZUCTS] (in Ukrainian)

Молотков П.И. (1972) Буковые леса Украинских Карпат. В кн.: Буковые леса СССР и ведение хозяйства в них (с. 78-109). Москва: Лесная промышленность. 200 с. [Molotkov, P.I. (1972). Beech forests of the Ukrainian Carpathians. In Beech forests of the USSR and conducting forestry in them (pp. 78109). Moscow: Forestry Industry] (in Russian)

Нормативно-справочные материаль для таксащии лесов Украины и Молдавии. (1987). Киев: Урожай. 560 c. [Normative and reference materials for forest taxation of Ukraine and Moldova (1987). Kiev: Harvest] (in Russian)

Остапенко Б. Ф., Ткач В.П. (2002). Лісова типологія. Харків: Харківський державний аграрний університет. 204 с. [Ostapenko, B.F., \& Tkach, V.P. (2002). Forest typology. Kharkiv: Kharkiv State Agrarian University] (in Ukrainian)

Постанова КМУ від 16 травня 2007 р. N 733 «Про затвердження Порядку поділу лісів на категорії та виділення особливо захисних лісових ділянок». (2007). Київ. [Resolution of the Cabinet of Ministers as of May 16, 2007 N 733 "On approval of the Procedure for division of forests into categories and allocation of spe- 
cially protected forest areas" (2007) Kyiv. Retrieved from https: //zakon.rada.gov.ua/laws/show/733-2007-\%D0\% BF\# Text] (in Ukrainian)

Правила рубок головного користування в лісах України (2009). Київ. [The rules for final fellings in forests of Ukraine. (2009). Kyiv. Retrieved from http:// zakon2.rada.gov.ua/laws/show/z0085-10] (in Ukrainian)

Свириденко В. Є., Бабич О.Г., Киричок Л. С. (2005) Лісівництво. Київ: Арістей. 544 с. [Svyrydenko, V.E., Babich, O. G. \& Kyrychok L. S. (2005). Forestry. Kyiv: Aristey] (in Ukrainian)

Сорока М.I. (2008). Рослинність українського Розточчя. Львів: Світ. 434 с. [Soroka, M.I. (2008). The vegetation of Ukrainian Roztochia. Lviv: Svit] (in Ukrainian)

Тышкевич Г.Л. (1984). Охрана и восстановление буковых лесов. Кишинев: Штиница. 232 с. [Tyshkevich, G. L. (1984). Protection and reproduction of beech forests. Kishinev: Shtiintsa] (in Russian)

Целень Я.П. (2006). Природне відновлення в букових лісах Стільського горбогір'я Львівської області. Лісове господарство, лісова, паперова $i$ деревообробна промисловість, 31, 131-138. [Tselen, Ya.P. (2006). Natural restoration in beech forests of Stilsky hill in Lviv region. Forest management, forestry, paper and woodworking industries, 31, 131-138] (in Ukrainian)

Myklush, S.I., Myklush, Y.S., \& Savchyn, V.M. (2017). Structure of the forest fund and functions of beech forests on Ukrainian plains. Scientific Bulletin of the Ukrainian National Forestry University, 27(8), 64-69. https://doi.org/10.15421/40270809

Pretzsch, H., del Rio M., Ammer, Ch., Avdagic, A., Barbeito, I., Bielak, K. ... Bravo-Oviedo, A. (2015). Growth and yield of mixed versus pure stands of Scots pine (Pinus sylvestris L.) and European beech (Fagus sylvatica L.) analysed along a productivity gradient through Europe. European Journal of Forest Research, 134(5), 927-947. https://doi.org/10.1007/ s10342-015-0900-4

Rubner, R. (1960). Die Pflanzengeographischen Grundlagen des Waldbaues. Berlin: Verlag Neumann-Neudamm. 620 s. [Rubner, R. (1960). The plant-geographical basics of silviculture. Berlin: Verlag Neumann-Neudamm] (in German)

\section{Mature beech stands in different categories of forests of the plain part of Ukraine}

\author{
S. Myklush', Y. Myklush², S. Havryliuk', \\ lu. Debryniuk ${ }^{4}$, V. Savchyn ${ }^{5}$
}

According to the forest fund accounting materials, the areas of mature beech stands estimated by Forest Management Organization were determined in 17 categories of forest. Forest stands up to 170 years are mature in the forests of nature protection objects. It was determined that the largest share of such stand (more than $57 \%$ of total area) is located in operational forests and $15.7 \%$ are concentrated in the forest management part of green areas. Mature beech stands grow in beech, oak, fir and pine types of forest. The largest area of beech stands is concentrated on the territory of the Western Forest-Steppe, namely in different forest vegetation conditions of the Ukrainian Roztochia, Opillya and Western Podillya. They prevail in the conditions of fresh oak-hornbeam beech forest type occupying more than 10 thousand hectares, as well as in wet oak-hornbeam beech type of forest occupying almost 8.5 thousand hectares. The stands are formed by the share of European beech from 2 to 10 units in the tree species composition. In some regions, along with European beech there are common oak, white fir (in Prykarpattia) and Scots pine (in Roztochia) in tree species composition and accompanying tree species are often represented by hornbeam, maple, birch and aspen. More than $52 \%$ of pure stands in terms of area and number of plots are concentrated in operational forests.

The most common are stands with a relative density of 0.5 , covering an area of almost 7.4 thousand hectares (1762 plots), while stands with a density of 0.7 cover area of 7.3 thousand hectares forming 1150 plots. Taking into account that plain beech forests perform 54 primary functions, among which the high importance is dedicated to the social and protective functions the structure of stands should be optimal for their effective

Stepan Myklush-Full Member of the Forestry Academy of Sciences of Ukraine, Doctor of Agricultural Sciences, Director of Educational and Research Institute of Forestry and Park Gardening, Professor of the Forest Inventory and Forest Management Department. Ukrainian National Forestry University, Heneral Chuprynky str., 103, Lviv, 79057, Ukraine. Tel.: 032-237-10-45, +38-067-791-3677. E-mail: msi_s@ukr.net ORCID ID: 0000-0002-9762-1190

Yuriy Myklush - PhD of Agricultural Sciences, associate professor of the Forest Inventory and Forest Management Department. Ukrainian National Forestry University, Heneral Chuprynky str., 103, Lviv, 79057, Ukraine. Tel.: 032-23927-46, +38-067-750-38-26. E-mail: y.myklush@nltu.edu.ua ORCID ID: 0000-0002-1940-1045

Serhii Havryliuk - $\mathrm{PhD}$ of Agricultural Sciences, associate professor, associate professor of the Forest Inventory and Forest Management Department. Ukrainian National Forestry University, Heneral Chuprynky str., 103, Lviv, 79057, Ukraine. Tel.: 032-23927-46, +38-068-760-91-99. E-mail: serhiy_havrylyuk@nltu.edu. ua ORCID ID: 0000-0003-0361-0624

Iurii Debryniuk - Full Member of the Forestry Academy of Sciences of Ukraine, Academician-Secretary of the Ukrainian Forestry Academy of Sciences, Doctor of Agricultural Sciences, Professor of the Department of Forest Crops and Forest Selection. Ukrainian National Forestry University. General Chuprynka str., 103, Lviv, 79057, Ukraine. Tel.: 032-23530-12, +38-067-195-78-36. E-mail: debrynuk_ju@ukr.net. ORCID ID: 0000-0002-0994-349X

Volodymyr Savchyn - production manager. Production Association "Ukrderzhlisproekt", Chaikovskoho str., 17, Lviv, 79005, Ukraine. Tel.: +38-097-011-40-47 E-mail: svm_25@ukr.net 
implementation of such functions over a long period. To achieve this recommended forming productive stands with a significant proportion of beech in the tree species composition. On average, the share of beech in tree species composition of the analyzed categories of forests and forest plots is in the range of 6.0-9.9 units. The largest share (more than 52\%) of pure beech stands are concentrated in operational category of forests. Mature beech stands in the forest management part of the forests of green areas are characterized by the highest productivity. The wood stock value in some stands reach 590-661 $\mathrm{m}^{3} \cdot \mathrm{ha}^{-1}$.

Taking into account the bioecological features of European beech, its ability to regenerate naturally and the functions performed forestry measures in mature beech stands to be aimed at its natural regeneration and gradual transformation into complex structures of different ages. Implementation of various functions by beech stands requires the application of such forest management measures that ought to meet the purpose of management at best; permanent preservation of the forest environment; strengthening the performance of certain functions and timely and high-quality natural regeneration of forest areas. Moreover, it calls for measures towards their gradual transformation into complex structures of different ages in most forest categories, including recreational \& health improving forests and forests that fulfil environmental and protective functions.

Key words: forest management materials; forestry; assessment indices; areas; functions; natural regeneration; final cutting.

\section{Спелые буковые древостои в различных категориях лесов равнинной части Украины}

\author{
С.И. Миклуш ${ }^{1}$, Ю.С. Миклуш ${ }^{2}$, С. А. Гаврилюк ${ }^{3}$, \\ Ю.М. Дебринюк ${ }^{4}$ В.М. Савчин
}

По материалам учета лесного фонда определены площади спелых буковых насаждений для выделенных лесоустройством 21 категории лесов и лесных участков. Установлено, что более $57 \%$ спелых древостоев по площади сосредоточено в эксплуатационных лесах и $15,7 \%$ - в лесохозяйственной части лесов зеленых зон. Спелые буковые насаждения растут в буковых, дубовых, пихтовых и сосновых типах леса, но преобладают в условиях свежей грабовой бучины, занимая площадь более 10 тыс. га и во влажной грабовой бучине - на площади 8,5 тыс. га. Насаждения формируются с участием бука лесного в составе от 2 до 10 единиц. В отдельных регионах, наряду с буком, в составе участвуют дуб черешчатый, пихта белая, сосна обыкновенная, а сопутствующими видами зачастую являются граб обыкновенный, клен-явор, клен остролистный, бере- за бородавчатая, осина. В эксплуатационных лесах сосредоточено более $52 \%$ площади чистых по составу древостоев. Наиболее распространенными являются насаждения с относительной полнотой 0,5, охватывающих площадь почти 7,4 тыс. га (1762 участка) и с относительной полнотой 0,7 , площадь которых составляет 7,3 тыс. га, которые растут на 1150 участках. Наивысшей производительностью характеризуются спелые буковые древостои в лесохозяйственной части лесов зеленых зон, где запасы стволовой древесины в отдельных насаждениях достигают 590-661 м ${ }^{3} \cdot \mathrm{ra}^{-1}$.

Выполнение буковыми насаждениями разноплановых средообразующих функций требует применения лесохозяйственных мероприятий, которые наиболее полно отвечают цели хозяйствования, постоянному сохранению лесной среды, усилению выполнения насаждениями определенных функций, своевременному и качественному естественному возобновлению лесных участков. В большинстве категорий лесов и лесных участков, в частности в рекреационно-оздоровительных леcax и лесах, выполняющих экологические и охранные функции, необходимо выполнять мероприятия для постепенного их переформирования в разновозрастные древостои сложной структуры.

Ключевые слова: материалы лесоустройства; лесоводственно-таксационные показатели; функции; естественное восстановление; рубки главного пользования.

Миклуш Степан Иванович - академик Лесной академии наук Украины, доктор сельскохозяйственных наук, директор HНI лесного i садово-паркового хозяйства, професор кафедры лесной таксации и лесоустройства. Национальный лесотехнический университет Украины, ул. Генерала Чупринки, 103, г. Львов, 79057, Украина. Тел.: 032-237-10-45, +38-067-791-36-77. E-mail: msi_s@ukr.net ORCID: 0000-0002$9762-1190$

2 Миклуш Юрий Степанович - кандидат сельскохозяйственных наук, доцент кафедры лесной таксации и лесоустройства. Национальный лесотехнический университет Украины, ул. Генерала Чупринки, 103, г. Львов, 79057, Украина. Тел.: 032239-27-46, +38-067-750-38-26. E-mail: y.myklush@nltu.edu.ua ORCID ID: 0000-0002-1940-1045

3 Гаврилюк Сергей Анатольевич - кандидат сельскохозяйственных наук, доцент кафедры лесной таксации и лесоустройства. Национальный лесотехнический университет Украины, ул. Генерала Чупринки, 103, г. Львов, 79057, Украина. Тел.: 032-23927-46, +38-068-760-91-99. E-mail: serhiy_havrylyuk@nltu.edu. ua ORCID ID: 0000-0003-0361-0624

4 Дебринюк Юрий Михайлович - академик Лесной академии наук Украины, академик-секретарь ЛАН Украины, доктор сельскохозяйственных наук, профессор кафедры лесных культур и лесной селекции. Национальный лесотехнический университет Украины, ул. Генерала Чупринки, 103, г. Львов, 79057, Украина. Тел.: 032-235-30-12, +38-067-195-78-36. E-mail: debrynuk ju@ukr.net ORCID: http://orcid.org/00000002-0994-349X

5 Савчин Владимир Николаевич - главный технолог. ПО «Укрдержлеспроэкт», ул. Чайковского, 17, г. Львов, 79005. Тел.: +38-097-011-40-47. E-mail: svm_25@ukr.net 